\title{
STAIRCASE TO SUSTAINABLE DEVELOPMENT
}

\author{
Mishelle DOORASAMY \\ Durban University of Technology, Department of Financial Accounting, Durban, South Africa \\ e-mail: mishelled@dut.ac.za
}

\begin{abstract}
The aim of this article to provide a theoretical framework on the concepts of Sustainable Development and the process that companies need to follow in order to ensure the future sustainability of business operations. Various secondary sources and previous literature was reviewed to clearly identify why companies are finding it difficult to conduct their business operations in a sustainable manner. Stricter legislation and regulations, increased competition, depletion of natural resources and market pressures have placed organisations under increased pressure to improve environmental performance and achieve eco-efficiency. This paper provides comprehensive overview of how companies can achieve the 'Triple bottom line' by committing to continuous improvement and adhering to the regulations stipulated according to the International Standards of Organisations (ISO14001).
\end{abstract}

Keywords: sustainable development, strict waste legislation, eco-efficiency, ISO14001, environmental performance, triple bottom line.

\section{$1 \quad$ Introduction}

In many developing countries, an increase in industrial activity, electricity demand and transportation results in emissions and poor air quality has become a major issue (Stringer 2010:34-35). Higher energy and raw material prices are causing sustainable production to grow in relevance and importance. Hence, the need for Cleaner Production (CP) and ecoefficiency which focuses on improved productivity and reduced impact as the result of design over the life of products, processes and services (National cleaner production strategy 2004:11; Lakhani 2007:1391). Since the amount of waste to landfill is increasing steadily, stricter waste legislations have been introduced. This is expected to have major implications for businesses that are conducting their business operations in an unsustainable manner. It has therefore extremely important for all companies to fully understand the process and procedures necessary to ensure their future sustainability and to commit to continuous improvement processes. Social, economic, and environmental performance are essential for a business to ensure its future sustainability.

\section{Sustainability}

\subsection{Sustainable development}

Sustainability became a topical issue almost two decades ago. Fore and Mbohwa (2010:314-333) point out that increased environmental problems, because of increased production and consumption, had contributed to the concept of sustainable development (SD). Early publication focused on the relevance of the environment to business and how this could be relevant for the role of accounting and alternative ways in which data can be processed. This was done using a 'Total cost assessment model'. As sustainability developed, the question was where and how would companies derive information needed to support the operational issues of various processes to ensure that the necessary data was available when required (Bennett, Schaltegger and Zvezdov 2013).

This has placed companies under pressure to adopt sustainability due to industry pressure and competition; stricter environmental regulation; pressure from stakeholders to monitor activities and outputs more closely; and increasing shortages of natural resources and higher energy costs. Since sustainability focuses more on non-financial information, there is a demand for companies to adopt new information systems or adapt their existing accounting system. 
The international community committed itself to sustainable development at the United Nations Conference on Environment and Development (UNCED) in Rio de Janeiro in 1992. SD is ultimately about development that meets the needs of the present generation without compromising the ability of future generations to meet their needs.

Others had interpreted sustainability as 'environmentalism dressed up for the $21^{\text {st }}$ century.' Sustainability was linked mainly towards creation of jobs and wealth in a fair manner and in ways that protect the environment (Environmental strategies 2013). Fore and Mbohwa (2010:314-333) concur that SD is not a business practice but rather a long-term goal of individual companies.

At the 2002 World Summit on Sustainable Development held in Johannesburg, a shift towards sustainable consumption and production was noted. Greater emphasis was placed on inefficient and wasteful use of natural resources (Resource Efficient and Cleaner Production 2013).

Issues raised at the summit clearly showed that much of the wealth generated in the country was at the expense of natural assets. Therefore, it was empha- sised at the forum that businesses need to take an active role in protecting these natural assets and reducing the environmental impact of operational activities (Ambe 2007:3). In 2006, a draft Strategic Framework for Sustainable Development in South Africa was used to reaffirm South Africa's commitment to implementing full measures to ensure that businesses cooperate and adopt a sustainable development approach to their business activities (Ambe 2007:4).Some researchers have argued that the root cause for environmental problems is the lack of an environmental management policy (Ahmad, Saha, Abbasi and Khan 2009:iv). Environmental and social aspects of business are not adequately recognised by current accounting systems and these issues may not be fully accounted for during decision making. Nonfinancial information is now being used to supplement the traditional financial information flows for external reporting and internal management needs. Sustainability accounting and production has encouraged companies to review their processes and products to take into account and respond to changing cost structures and risks (Bennett, Schaltegger, and Zvezdov 2013).

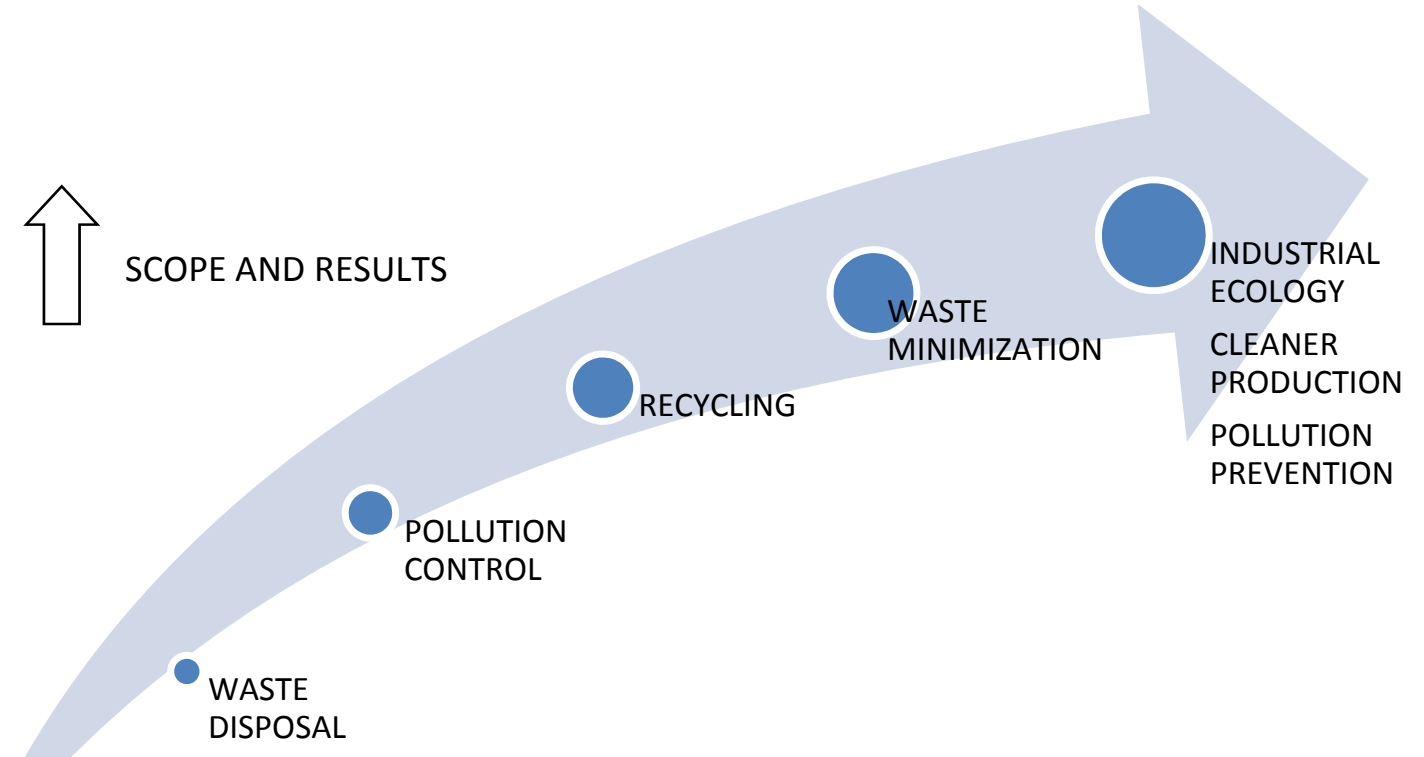

TIME AND WORK

Environmental management systems

Figure 1. Staircase of Concepts aiming Sustainable Development

(source: Nabais 2011:4) 
Thereafter, the "Triple Bottom Line" became widely accepted as a company level approach to sustainability. Hence, businesses had to focus on and manage their environmental, social and financial performance (Schaltegger et al. 2010).

Sustainability, however, continues to pose a challenge to companies that are struggling to design a systematic approach to address all three aspects stated above. EMA then became recognised as a prioritized intervention that integrates the ecological and economic dimensions necessary for SD (Ambe 2007:4).

Fig. 1 demonstrates the key concepts aimed at SD.

EMA and the balance scorecard were introduced to industry as a means to measure sustainability factors to compare and benchmark environmental performance (Lambert, Carter and Burritt).

Fig. 1 highlights key concepts of SD. Each step involves more time and greater effort on the part of organisations aimed at achieving zero emissions. From the above evidence, it is clear that SD is a long-term strategy involving step-by-step processes of development and progress towards achieving the ultimate goal, as depicted in Fig. 1.

\subsection{Environmental management}

a) International standards of organisation (ISO 14001)

Bennett, Schaltegger and Zvezdov (2013) describe environmental standards such as ISO14001 and Environmental Management Accounting Systems (EMAS) as voluntary standards that act as a form of regulatory governance as they become institutionalised and internationally recognised. Its aim is to make cost relationships transparent and provide guidance during process and product design decisions by adopting conventional costing systems. They believe the purpose of ISO 14001 is to help companies implement environmental management systems (EMS) that fulfil certain criteria. Ahmad, Saha, Abbasi and Khan (2009:v) concur that the ISO 14001 EMS could be used by managers to assess and measure progress and performance by providing standard auditing, communicational and reporting protocols. Complementary standards such as ISO 9001 have been found to be the most relevant factors for adopting ISO 14001 or EMAS. Li (2004:1) found an enhanced development of EMA among companies that were ISO 14001 certified. This has also encouraged governments to promote EMA implementation within countries.

The availability of win-win possibilities and leadership by individuals in the company management had been reported as the most common internal factors that influence the implementation of standards.

b) "Best practices" of environmental management

Christmann (2000:13-17) analyzed three processfocused "best practices" of environmental management during his research to identify their direct effect on cost advantage:

- Best practice 1: Use of pollution-prevention technologies

Pollution-prevention technology has the potential to increase the efficiency of the production through reduced input costs, substitution of less costly inputs, savings from recycling or reusing materials, and reduction of waste disposal costs;

- Best practice 2: Innovation of proprietary pollution-prevention technologies

Internal innovation of pollution-prevention technologies contribute to the firm's cost advantage in many ways: First, managers become aware of inefficiencies in current production processes and products that were not previously recognized, by developing new pollution-prevention technologies. Second, innovation of pollution-prevention technologies has greater potential for cost-saving changes in the production process. Third, the technologies are proprietary to the firm, therefore, the firms are likely to appropriate the rents that are created by these internally developed technologies. Competitors are not easily able to imitate these internally developed pollution-prevention technologies; and

- Best practice 3: Early timing

Addressing environmental issues earlier than competitors or before environmental regulation is established contributes positively to cost advantage by minimizing disruptions of the production process usually caused by implementing compliance technologies, allowing the firm to gain cost advantage 
through the learning curve effects, by addressing environmental problems early and influencing regulations can raise their competitors' costs.

Holt (2009) views ISO 14001 as a logical extension of the quality management system ISO 9001. Some researchers advocate that both quality improvement and environmental investments can have positive effects on a firm's competitiveness (Orsato 2006:129-130).

The King Commission (2002:240) cite the following nine reasons for businesses to improve its environmental performance, as per The United Nations Global Compact, noted by Mohr-Swart (2008:102):

- implementing CP and eco-efficiency improves resource productivity,

- clean companies are being rewarded by new economic instruments,

- stricter environmental regulations,

- cleaner companies are seen as low risk and also preferred by insurance companies,

- banks are more willing to provide financial assistance to cleaner companies,

- positive effect on company's image,

- health and safety of employees,

- negative impact of pollution to human health, and

- pressure from customers for cleaner products.

Radonjic and Tominc (2007:1482-1493) conclude that ISO 14001 certified firms were more productive and achieved better environmental performance.

They also found that the adoption of cleaner technologies were more likely among certified companies as ISO 14001 was considered a useful tool for technology changes in companies which were committed to the IPPC directive. Hence, it can be suggested that being ISO certified means that an organisation has committed to ensuring that it complies with the continual improvement policy and, therefore, would be more likely to consider implementing $\mathrm{CP}$ techniques and technologies to achieve SD.

However, even though companies are ISO 14001 accredited, many of them are unaware that this is just the start towards their commitment to SD and greater effort and change is required to actually reach targets set in their policies. Despite emerging best practices, there is still much discrepancy regarding corporate environmental strategies and its impact on environmental performance across many organisations. According to Sinclair-Desgagne (2004:7), the biggest challenge that firms are currently facing is the difficulty in integrating environmental issues into day-today business activities. Gil, Andres and Salinas (2007:89) argue that management commitment and awareness of environmental responsibility significantly influence corporate strategy. SinclairDesgagne (2004:7) suggests that all business units need to be involved in environmental goal-setting and implementation in order to successfully achieve environmental objectives. Many of the goals stated in environmental policies have not been achieved due to lack of commitment to move past pollution control and waste disposal strategies. Most companies are just content to satisfy the minimum requirements of an ISO 14001 audit without changing or improving their production processes or technologies.

\section{c) Environmental management systems}

\section{Definition and framework of EMS}

Ferenhof, Vignochi, Selig, Guillermo, Lezana, and Campos (2014:44-53) define EMS as a tool aimed at reconciling economic growth with the environment and is used to support a company with systematic processes for implementing environmental goals, policies and responsibilities, as well as regular auditing of its elements.

They recommended that EMS designed for an organization must take into consideration the operation's activities and how the company's actions impact the environment and an environmental indicator system be used to identify potential opportunities for cost reduction and improve environmental performance. ISO 14001 provides a useful framework for promoting efficient EMS which should be part of an integrated system of management.

Radonjic and Tominc (2007:1482-1493) added that EMS is an important part of the pollution-prevention approach. The manufacturing process performance is improved and impacts of process upsets and equipment failure are greatly reduced by the adoption of sound EMS. 
Compliance to environmental laws and regulations adoption. However, Henriques and Sadorsky (2007: 119-132) disagree with the above hypothesis and found that EMS reduces the likelihood that an organisation will implement clean technologies while Total Quality Management (TQM), on the other hand, increases the chances of an organisation implementing clean technologies. They do, however, admit that EMS systems provide the platform for promoting innovation in organisations as part of their proactive environmental strategy. In addition, Ahmed et al. (2009:iv) advocate that EMS cannot function in isolation and needs to be incorporated into the main corporate agenda.

They believe that an EMS can merely provide an administrative and systematic structure to be utilized as a sustainable environmental management mechanism, but cannot provide guidelines on how to achieve sustainability. However, the argument of whether or not proactive environmental activities increase business performance remained unresolved for many researchers (Darnall, Henriques and Sadorsky 2008:364-376). as well as innovation is also facilitated through EMS Brent and Premraj (2007:31) found that, although studies show that environmental performance may improve by adopting a formal EMS, there were still unclear guidelines on how to effectively implement an EMS system.

It can, therefore, be concluded that one needs to have a clear definition of sustainability and integrate this as part of the strategic planning process and policy development. It is only then that an EMS could be used as a tool to successfully achieve sustainability targets.

Effective EMS for manufacturers of pulp and paper include spill prevention and control, preventative maintenance, emergency preparedness and response, and energy efficiency programmes. EMS enables companies to implement preventative-maintenance programmes to identify and repair equipment before it fails and thereby avoid large releases to the environment.

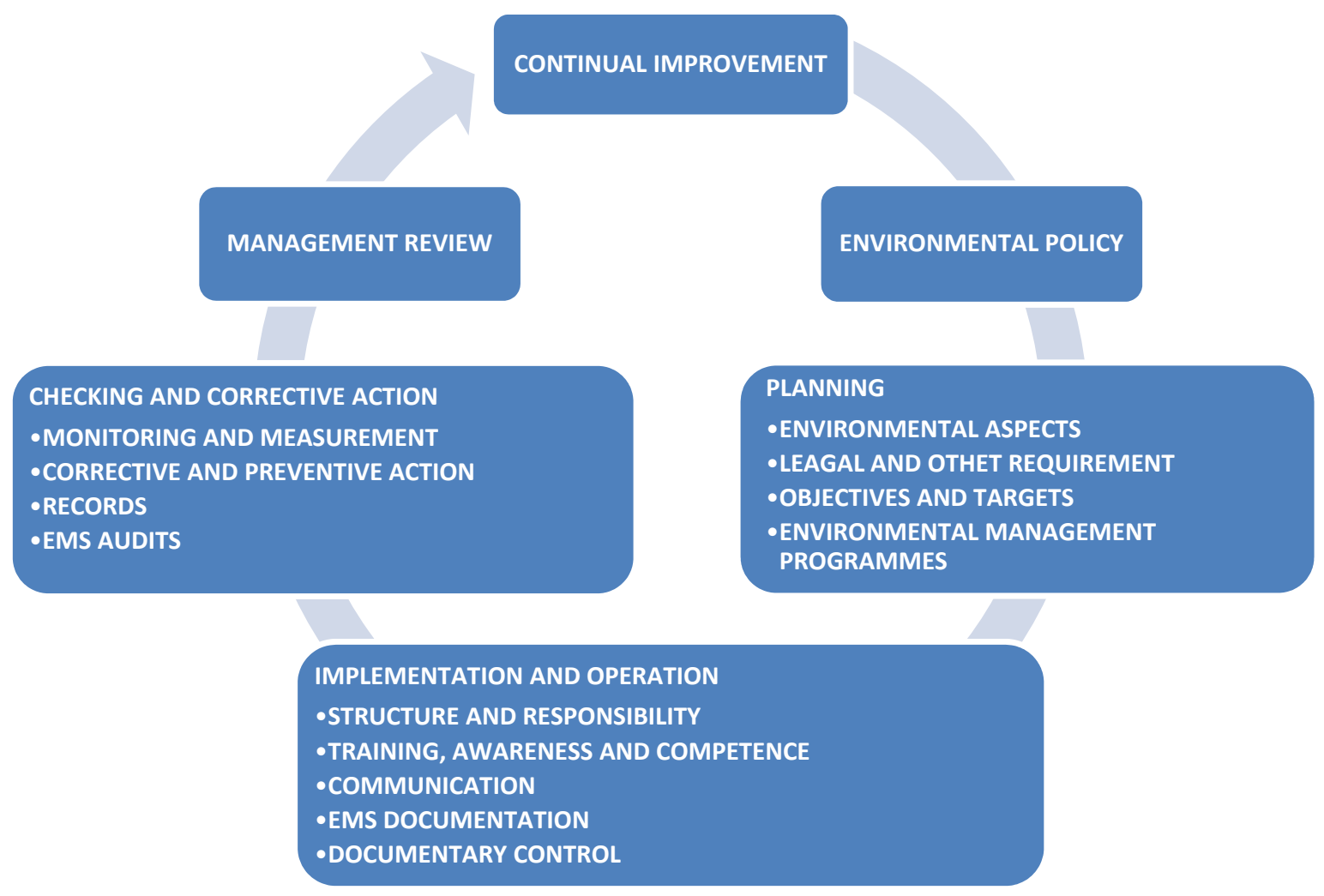

Figure 2. The EMS approach: "Embedding” Environmental Issues (source: Holt 2009) 
Proactive measures, made possible by adopting an EMS, tend to reduce and control unnecessary losses that would be incurred by companies. Internal audits are carried out to assess the performance of the EMS and the International Standards Organization recognizes the importance of such a system. ISO 14001 has stated the key elements of an EMS and include the following:

- vision as defined by the environmental policy,

- objectives and targets for environmental performance,

- programmes to achieve those targets,

- ways to measure and monitor the system's effectiveness, and

- periodic review of the system to improve overall environmental performance.

ISO 14001 focuses on the management process, not on its content and performance. Manufacturers can develop their goals and objectives to achieve continuous environmental improvement (Henriques and Sadorsky 2007:119-132).

Holt (2009) highlights the following EMA information that an EMS provides:

- monitoring, compliance and performance data that is routinely collected,

- increasing the visibility of cost saving options to managers, and

- inaccuracies in the allocation of environmentrelated "overhead" costs are revealed.

Fig. 2 indicates elements of an EMS within an organisation, which is based on the principle of continual improvement.

\subsection{Environmental Management Accounting (EMA)}

a) Development and theoretical framework of EMA

Environmental changes and future threats can generate higher costs to the company. The strategic operational issue is that companies are not aware of the magnitude of these costs as they are generally hidden in overhead accounts. Greater transparency of these costs ensures that they are being managed in a way that results in environmental and economic benefits (Jonall and Olson: 2008).

Initially, the reaction to environmental challenges was to disperse pollutants better to reduce their harmful impact on communities. Thereafter, the environmental management paradigm was to implement measures to control pollution and treat wastes after they have been created. Examples include effluent treatment plants, catalytic converters and waste incineration, also referred to as end-of-pipe technologies (Environmental strategies 2013).

However, the current management accounting systems were inadequate to provide the information on monetary and physical environmental impacts.

Therefore, EMA was introduced. EMA has been developed and applied for nearly two decades and has now emerged from a "twenty year niche issue" to a globally popular topic in academia and industry. Abdel-Kader (2011:63) asserts that the first publications on EMA was the World Resources Institute's "Green Ledgers" in which it had been argued that environmental-related costs were significantly underestimated and frequently accounted for as general overheads. Conventional income statements created a perception that environmental costs are limited to separately identified items such as fines and penalties, "end-of-pipe" pollution control equipment and expenditure to remediate past environmental damage, all of which are defensive expenditures. Therefore any potential to improve environmental and economic performance by cost reductions, developing new revenues and managing risks are ignored, was clearly pointed out by Abdel-Kader (2011:64).

Benette, Schaltegger and Zvezdov (2013) developed a working definition for EMA as "a tool for transforming physical and financial measures of environmental data into information for decision making to judge environmental performance". Qian, Burritt and Monroe (2011:93-128) added that EMA is used to identify, collect and analyse both physical and monetary information for internal decision making.

Physical information comprises of data on use and flows of energy, water, and materials including waste, whereas monetary information is based on environment-related costs, savings and earnings 
and environmental costs that are generally hidden under overheads. As per International Federation of Accountant (IFAC), EMA is defined as the development and implementation of environment-related systems and practices to manage environmental and economic performance (Schaltegger et al. 2010). Furthermore, EMA is an approach of corporate environmental management involving the application of accounting tools and practices to assist managers in decision making on environmental and economic performance (Schaltegger, Gibassier and Zvezdov 2011:2). Li (2004:1) suggests that, in a contemporary world, EMA should be used in the strategic development process to create a balancing interaction between economic, social and technological factors to ensure a sustainable environment.

In all of the definitions of EMA stated above, the types of information that should be considered by organisations and analysis techniques adopted for internal decision making to maximize profitability are highlighted.

However, the main objective of an EMA system, as suggested by Scavone (2006:1276-1285), is the introduction of ongoing environmental preservation activities and disclosure of the company's environmental position internally and to its stakeholders. EMA adoption makes it possible for an organisation to be able to generate high quality informational reports containing both monetary and non-monetary data. Monetary data is extracted from the data base that supports financial reports and is used by management to make informed business decisions.

The United Nations Development Program as part of the Department of Sustainable Development reports EMA as an important management tool that is of benefit to both industry and government. They (UNEP) have embarked on several activities to educate and encourage companies of the benefits of using EMA.

One of the activities was being part of the expert working group on EMA which introduced the international guidance and also developing training course in EMA. This publication offered a set of principles and procedures for EMA based on that which was commonly used in Financial Accounting methods with the intention of reducing the cost of adopting an EMA system (Jasch 2003:667-676).
Following these international developments, South African companies have considered environmental issues in their decision- making processes regarding products and processes. It has been suggested that EMA is a valuable tool for businesses to adopt whilst responding to environmental challenges and still focusing on the triple bottom line (Ambe 2007:7). At the time of the study, there was an apparent lack of awareness and understanding of the significance of the environmental costs and their impact on the overall performance of the organization. What had been brought to the forefront was the potential savings to South African companies by implementing good environmental management by using EMA to accurately trace and identify environmental costs (Ambe 2007:11-12). It can, therefore, be concluded that Environmental Accounting can be used to demonstrate the potential for environmental investment to yield financial benefits to an organization.

Qian and Burritt (2008:244) added that multidisciplinary knowledge, information and skills as well as inter-professional communication are needed for EMA. Recent developments in EMA emphasise the greater need for accounting information when making decisions regarding environmental projects (Qian and Burritt 2008:244).

Hence, communication between the accounting department and the environmental management department is crucial if an organisation wishes to succeed in EMA implementation. Accountants play an important role as they are expected to access the data and analyse variables associated with various environmental costs. In addition, there is also need to assess whether or not costs have been allocated and handled correctly and in accordance to environmental policies and guidelines. Therefore, in order to gain maximum benefits of EMA, an integrated system that provides comprehensive information is thus needed.

Scavone (2006:1276-1285) states that, by adopting an EMA system, a company can develop proactive environmental programmes which, in turn, improve profitability and competitiveness, reduce business costs, increase worker productivity and morale, enhance brand image, and improve relations with regulators and local communities. 
Table 1. Environmental costs of a company

(source: Jasch 2009)

\begin{tabular}{|l|l|}
\hline & Environmental Protection Costs (Emission Treatment and Pollution Prevention) \\
\hline+ & Costs of wasted material \\
\hline+ & Costs of wasted capital and labour \\
\hline$=$ & Total corporate environmental costs \\
\hline
\end{tabular}

She believes that companies that adopt proactive measures to address environmental issues are in an excellent position to identify problems and opportunities to introduce innovative solutions. It is essential for companies to generate reliable past and futureoriented information by using environmental accounting decision tools such as EMA, to enable effective and efficient management of environmental consequences of the business operations.

Godschalk (2008:259) explains that a company can reduce its exposure to environmental risks and liabilities by being proactive and being aware of possible environmental costs and savings available during their strategic planning phase. Hence, there is an increased need for systems that can provide reliable, accurate physical and monetary environmental information. This, in turn, would assist in meeting the needs of customers and other stakeholders that have a vested interest in the company's operational activities.

Qian, Burritt and Monroe (2011:93-128) emphasise the incompleteness of conventional management accounting approaches by using terms such as "true", "total", "comprehensive", and "life cycle". Decisions based on conventional accounting practices only take into consideration the operational costs of waste management as compared to EMA, which generates both financial and non-financial information that is used by managers to support internal environmental management processes.

They pointed out that companies do not consider alternatives such as resource recovery and material recycling as disposal to landfill is considered as the most feasible and competitively attractive option because of the low operation costs of landfill disposal. This is caused by incorrect calculation of actual environment cost by current management accounting systems. As a rule in environmental management, 80 percent of environmental costs are caused by 20 percent of production activities undertaken by an organisation. Under traditional accounting, these costs are blocked under overhead accounts and thus shared by all product lines, thus, leading to incorrect estimation of product prices and reduced profitability of the organisation (Bennett, Rikhardsson, and Schaltegger 2003). According to Jasch (2008), during decision making, the cost of wasted materials, capital and labour need to be added to assess the value of total corporate environmental costs.

Table 1 shows the internal calculation of environmental costs by a company. Table 1 indicates that, when calculating environmental costs, the purchase value of wasted material and the production costs of waste and emissions must be considered.

Ambe (2007:6) clarifies the following shortcomings of conventional management accounting practices in environmental cost consideration during internal decision making:

- many environmental costs were "hidden" in overhead accounts,

- the allocation of environmental costs from the overhead accounts were thereafter incorrectly allocated to processes and products,

- some environmental costs were incorrectly considered "fixed" instead of "variable",

- volume and cost of wasted raw materials were incorrectly calculated,

- relevant and significant environmental costs were excluded completely from accounting records resulting in environmental costs being understated, and

- EMA information is not considered during investment appraisal. 
In response to the abovementioned shortcomings of conventional management accounting system and increased environmental challenges, EMA was suggested as a valuable business tool for implementation by organisations to create a better link between environmental and economic performance (Ambe 2007:6). This made it possible for businesses to achieve the triple bottom-line without compromising the environment.

Godschalk (2008:262) concluded that, ultimately, the internally-orientated benefits of adopting EMA are as follows: assist organisations in achieving competitive advantage, greater cost-efficiency, and improved image and customer relations. Olson and Jonall (2008:8) stress the importance of having a more structured accounting system in increasing cost efficiency and improving environmental performance. Incorrect cost allocation leads to incorrect decision making. Therefore, tracing cost to the actual cause of it, either a process or product rather than reflecting it under overhead accounts, is extremely important, especially in strategic decision making.

Olson and Jonall (2008:8) illustrate the principle of cost allocation in the Table 2 by demonstrating the impact of incorrect environmental cost allocation.

Table 2 shows that if environmental costs were shared equally between both processes, an incorrect profit amount would be generated which, in turn, will impact on future investment decisions. Hence, process A would not have been given preference over project B. Therefore, in order to ensure that transparent, accurate environmental costs are allocated to the actual process or product, an EMA system would be most appropriate to implement in the future.

Table 2. Impact of environmental cost allocation (source: Olson and Jonall 2008:8)

\begin{tabular}{|l|c|c|}
\hline \multicolumn{1}{|c|}{$\begin{array}{c}\text { Examples: 1) without, } \\
\text { 2) with Environmental overhead cost }\end{array}$} & "Clean” process A \\
\hline Correct environmental cost allocation & $\$ 200$ & $\$ 200$ \\
\hline Revenues & $\$ 100$ & $\$ 100$ \\
\hline Production costs & $\$ 0$ & $\$ 50$ \\
\hline True Environmental costs & $\$ 100$ & $\$ 50$ \\
\hline True profit & & $\$ 200$ \\
\hline Incorrect environmental cost allocation & $\$ 100$ & $\$ 100$ \\
\hline Revenues & $\$ 25$ & $\$ 25$ \\
\hline Production costs & $\$ 75$ & $\$ 75$ \\
\hline If environmental costs are overhead & $-25 \%$ & $+50 \%$ \\
\hline Illusory profit & & \\
\hline The latter (2) is incorrect by & & \\
\hline
\end{tabular}


Table 3. Environmental Cost Categories

(source: Introducing Environmental Management Accounting at Enterprise Level 2001:9)

\begin{tabular}{|c|c|c|c|c|}
\hline $\begin{array}{c}1 \\
\text { Waste } \\
\text { and emission treatment }\end{array}$ & $\begin{array}{c}2 \\
\text { Prevention } \\
\text { and environmental } \\
\text { management }\end{array}$ & $\begin{array}{c}3 \\
\text { Material pur- } \\
\text { chase value } \\
\text { of non-product } \\
\text { output } \\
\end{array}$ & $\begin{array}{c}4 \\
\text { Processing cost } \\
\text { of non-product } \\
\text { output }\end{array}$ & $\begin{array}{c}5 \\
\text { Environmental } \\
\text { revenues }\end{array}$ \\
\hline $\begin{array}{l}\text { 1.1 Depreciation } \\
\text { for related equipment }\end{array}$ & $\begin{array}{l}\text { 2.1 External services } \\
\text { for environmental } \\
\text { management }\end{array}$ & $\begin{array}{l}\text { 3.1 Raw } \\
\text { materials }\end{array}$ & $\begin{array}{l}\text { 4.1 Labour } \\
\text { costs }\end{array}$ & $\begin{array}{l}\text { 5.1 Subsidies, } \\
\text { Awards }\end{array}$ \\
\hline $\begin{array}{l}1.2 \text { Maintenance } \\
\text { and operating materials } \\
\text { and services }\end{array}$ & $\begin{array}{l}\text { 2.2 Personnel } \\
\text { for general environ- } \\
\text { mental management } \\
\text { activities }\end{array}$ & 3.2 Packaging & $\begin{array}{l}\text { 4.2 Energy } \\
\text { costs }\end{array}$ & 5.2 Other earnings \\
\hline 1.3 Related Personnel & $\begin{array}{l}\text { 2.3 Research } \\
\text { and Development }\end{array}$ & $\begin{array}{l}3.3 \text { Auxiliary } \\
\text { materials }\end{array}$ & & \\
\hline $\begin{array}{l}\text { 1.4 Fees, taxes } \\
\text { and charges }\end{array}$ & $\begin{array}{l}\text { 2.4 Extra expenditure } \\
\text { for cleaner technolo- } \\
\text { gies }\end{array}$ & $\begin{array}{l}\text { 3.4 Operating } \\
\text { materials }\end{array}$ & & \\
\hline 1.5 Fines and penalties & $\begin{array}{l}2.5 \text { Other environmen- } \\
\text { tal cost management }\end{array}$ & 3.5 Energy & & \\
\hline $\begin{array}{l}\text { 1.6 Insurance for envi- } \\
\text { ronmental liabilities }\end{array}$ & & 3.6 Water & & \\
\hline $\begin{array}{l}1.7 \text { Provision for clean- } \\
\text { up costs remediation }\end{array}$ & & & & \\
\hline
\end{tabular}

Various reports, including guidelines and recommendations for implementing EMA, have been published by the United Nations Division on Sustainable Development (UNDSD) and the International Federation of Accountants (IFAC) (Schaltegger, Gibassier, and Zvezdove 2011:1). However, every company would have a different goal and vision according to its needs and available resources for environmental-related activities. Hence, EMA should be customized to suit the needs and requirements of individual organisations. It is, therefore, suggested that the current management accounting system of a company be adapted to include environmental cost information.

Table 3 represents a summary of the main environmental cost categories found in businesses.

Table 3 was developed by the UNDSD in 2001 and provides a framework and guidelines on environ- mental cost categorisation. Hence, this information could be useful to companies that want to implement EMA as part of their continuous improvement policy.

Jasch (2003:667-676) claims that this comprehensive framework for EMA ensures that all relevant and significant costs are considered during decision making.

Cost allocation by EMA could result in the following benefits (Introducing Environmental Management Accounting at Enterprise Level 2001: 9):

- pricing of products could change due to recalculation of costs,

- profit margins of products could be re-evaluated;

- decision to phase out products because of high environmental cost,

- processes and procedures may be re-designed to reduce environmental cost, 
Table 4. EMA methods

(source: Burritt, Haun and Schaltegger 2002:43)

\begin{tabular}{|l|c|c|c|c|c|}
\hline \multicolumn{1}{|c|}{ Time } & Type of report & $\begin{array}{c}\text { Physical } \\
\text { short-term }\end{array}$ & $\begin{array}{c}\text { Physical } \\
\text { long-term }\end{array}$ & $\begin{array}{c}\text { Monetary } \\
\text { short-term }\end{array}$ & $\begin{array}{c}\text { Monetary } \\
\text { long-term }\end{array}$ \\
\hline past-oriented & routinely generated & $\mathrm{X}$ & $\mathrm{X}$ & $\mathrm{X}$ & $\mathrm{X}$ \\
\hline & $\mathrm{ad}$ hoc & $\mathrm{X}$ & $\mathrm{X}$ & $\mathrm{X}$ & $\mathrm{X}$ \\
\hline future-oriented & routinely generated & $\mathrm{X}$ & $\mathrm{X}$ & $\mathrm{X}$ & $\mathrm{X}$ \\
\hline & ad hoc & $\mathrm{X}$ & $\mathrm{X}$ & $\mathrm{X}$ & $\mathrm{X}$ \\
\hline
\end{tabular}

- continuous monitoring of environmental performance and good housekeeping measures implemented, and

- unnecessary costs are eliminated.

The framework for EMA proposed is by Burritt, Haun, and Schaltegger (2002) on categories of different EMA methods based on the attributes of the information and the uses to which the information is to be applied.The 16 categories in which different EMA methods can be positioned and understood in terms of their purpose and data source are demonstrated in table 4 (Bennett, Schaltegger, Zvezdov 2013).

Table 4 explains the categories of EMA information generated as follows:

- information is monetary and non-monetary (physical),

- measure past performance or to make decisions for the future,

- distinguished between decision involving strategic information over several years and more operational information covering shorter time periods, and

- how routinely the information is provided regularly for a recurring purpose or on an ad hoc basis for a specific non-recurring need.

Monetary EMA methods rely on corresponding physical information about materials and energy flows and are past-oriented. This type of information can provide managers with an overview of inefficiencies in material and energy usage which is useful in identifying and analysing potential improvement opportunities.

Bennette, Shaltegger and Zvezdov (2013) reported that past-oriented information is found most often in businesses. However, once managers become aware of opportunities for efficiency improvements and other benefits, then future-oriented information will also be needed. Firms will thus be able to achieve first mover advantage by being proactive in strategic planning. It would be up to management to decide which tools would best suit their information needs.

Hyrslova (2011:47) states that, within the EMA framework, it is necessary to analyse the individual activities and processes to prepare material and energy balances in order to understand waste flows and express these flows in monetary units to ensure that all significant costs are considered when making business decisions. According to Jasch (2008), any waste generated is a sign of inefficient production based on the underlying assumption that all purchased materials must leave the company either as a product or waste and emission. Therefore, it can be concluded that an EMA system provided much more valuable information to support decision making within an organisation than a traditional management accounting system.

The concept of EMA is not clear to many individuals in an organisation and is conceived as a system that merely monitors and reports environmental costs. Jasch (2008:4) argues that "Doing environmental management accounting is simply doing better, more comprehensive management accounting, while wearing an "environmental" hat that opens the eyes for hidden costs." It should be noted that management of environmental-related costs is important even before reporting them. Hence, environmental and financial performance is managed and improved by adopting an EMA system (Schaltegger et al. 2010: 47). 
During a study conducted by Ambe (2007:7), external factors influencing EMA adoption were discussed, as follows:

- increased stakeholder pressure concerning environmental issues,

- greater need for integration of physical and financial aspects of environmental management, and

- combined financial, environmental and social consideration incorporated into concepts of sustainable development and corporate social responsibility; and greater environment-related costs.

Although environmental accounting forms an important part of industrial decision making in first world countries, there is however a lack of commitment to the environment in South Africa (De Beer and Friend 2006). Environmental Assessment (EA) is an integral component of environmental regulatory systems in developing countries like South Africa. It is one of the most important emerging trends in national environmental legislation. The EA process can contribute to effectiveness of the environmental regulatory system by integrating environmental considerations into the planning and appraisal of development activities. It can contribute to an improvement in environmental performance and cost effectiveness of the environmental regulatory systems.

Following great developments internationally, South Africa began to place emphasis on environmental impact during decision making on processes and products, more especially in the context of energy and raw material consumption and the resulting waste of production processes. Despite commitment from government and many organisations, the level of EMA application still remains low. Ambe (2007:11) concluded that EMA implementation in developing countries was still at its infancy stage. Conventional cost accounting systems are still used by the majority of organisations in South Africa as managers do not actually see benefits of detailed environmental costing. Company managers believe that developing new systems are expensive and traditional systems are perceived as adequate for reporting purposes.

\section{b) Theoretical perspectives of EMA}

There are various theories that researchers have studied to identify the motivational reasons for EMA adoptions.

The two categories most commonly researched are the social theory and the organisational theoretical perspectives. Both these theoretical perspectives are explained briefly below.

Environmental reporting and environmental audit research are sometimes based on the "stakeholder theory". The stakeholder theory implies that organisations need to place greater emphasis on stakeholders and ensure that a two-way communication is facilitated as stakeholder interest is considered critical to a firm's success (Godschalk 2008:250). Some researchers argue that, in order to ensure sustainability of the company, the legitimacy theory must be applied. This implies that a company needs to conduct their business operations in a way that is socially acceptable by the community. Schaltegger et al. (2010:262) believe that stakeholder relations can be improved by enhancing benefits they receive from improved environmental performance. The company needs to disclose its activities to ensure continuity. The stakeholder theory and legitimacy theory are similar in that they are both take an open system's view of organisations (Qian, Burritt and Monroe 2011:93-128). These theoretical perspectives relate specifically to corporate environmental accounting.

On the other hand, a contrasting view to both theories mentioned above is the institutional theory that views the organisation as part of the larger system in which it operates. Qian, Burritt and Monroe (2011:93-128) argue that the institutional theory is more applicable to explaining motivations for adopting environmental management accounting in organisations. They also defined the contingency theory as a competing theory for environmental management accounting. Jalaludin, Sulaiman and Ahmad (2011:540-557) conducted a study aimed at understanding the relationship between EMA adoption and institutional pressure using multiple regression analysis.

They reported that institutional pressure in terms of training and education did, to some extent, influence EMA adoption in organisations. 
Bennette, Schaltegger and Zvezdov (2013) discussed the impact of the contingency theory on environmental accounting. They stated that there is no single best approach to sustainability in a company.

Instead, the optimal course of action is dependent (contingent) upon the circumstances in each case and upon relevant factors such as the company's environment, technology and culture.

Qian, Burritt and Manroe (2011:93-128) argue that an organisation's contextual dynamics are just as important and needs to be considered when analysing environmental changes in organisations.

Since the external business environment is characterised by uncertainty, the contingency theory seems most appropriate during analysis of environment performance of an organisation. The contingency theory is a strategic management-based organisational theory which focuses mainly on efficiency and technical organisation rather than on motivational factors for adoption of EMA. It is, therefore, evident from the above review that there is no set theory to explain EMA implementation. According to Qian, Burritt and Monroe (2011:93-128), the view of the contingency theory is that organisations are driven by task performance. They believe that the effectiveness of management control systems is contingent upon its business environment and contextual situations. Hence, it is both the contingency factors and the uncertain organisational environment that support the development of EMA within the organisation.

\section{c) Challenges of EMA implementation}

Several factors make it difficult for the implementation of EMA in an organisation. Poor adoption of EMA in many industries increased the need to investigate some of the challenges experienced by companies.

Ferenhof et al. (2014) mention some challenges to adopting EMA that they discovered during research: implementation of EMA has a lack of organisation incentives at the start as some companies perceive disclosure of accounting information as risky. It is only when they can actually see results in monetary terms do they realise that the business is improving because of actions taken.
Accountants are usually unaware of information improvements that could be obtained by using EMA methodology when they design an accounting system, making it difficult for effective collection and evaluation of environment-related information. De Beer and Friend (2006) added that deficiencies in institutional capacities, untrained staff, shortages of resources as well as inadequate base-line data and environmental monitoring have been identified as some of the shortcomings in current regulatory systems in middle-income countries. Furthermore, research shows that there are poor communication links between accounting and other departments in an organization. As a result, information used by management for decision making may be inaccurate.

Inconsistencies in the type of information system used by the accounting and technical departments also make it difficult to track and trace certain environmental costs accurately (Shcaltegger et al. 2010).

During a study done in China, Li (2004:1) claimed that problems related to EMA were the poor specification of environmental accounting information, allocation of environmental costs, legislation issues, and lack of environmental accounting standards. Hence, stricter regulatory compliance is necessary for companies to implement EMA systems and procedures because, if this is optional, many organisations would not likely want to make the change even though they may be aware of the potential benefits of the systems. They view such changes as "not worth their while". Conversely, Ahmed et al. (2009:14) point out that "Environmental considerations are considered to be accompanied only by costs or as counterproductive to economic growth".

Some barriers that EMA helps to overcome, as mentioned by Olson and Jonall (2008:40), are management commitment by making managers aware of actual environmental costs, information inconsistency, becoming more efficient and focused, thus resulting in improved environmental and economic performance, and promoting better quality of products through reducing the amount of defective products. In conventional cost accounting, both environmental and non-environmental costs are included under overhead accounts and hidden from management, resulting in incorrect decision making. 


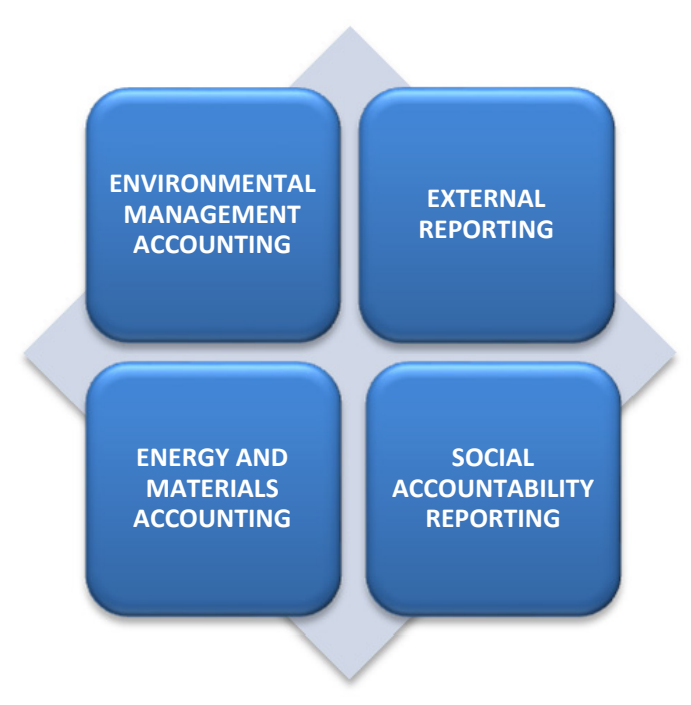

Figure 3. Internal and external reporting of financial and non-financial data

Fig. 3 clearly demonstrates the four approaches to environmental accounting (Olson and Jonall 2008:19). Fig. 3 depicts the EMA approach, including the internal, external, financial and non-financial perspectives (Bartholomeo et al. 2000).

EMA, as described by Olson and Jonall (2008:19), is a combined approach representing the transition of data from financial accounting, cost accounting, and material flow cost accounting.

Material flow balances, in physical units within a defined system, form the core part of Environmental Information System.

\section{d) Empirical evidence of EMA}

A large number of pilot testing projects have been conducted on EMA, demonstrating its positive contribution towards companies achieving both environmental and economic targets (Qian et al. 2011:9328; Khalid and Dixon 2012:3; Bennette, Schaltegger and Zvezdov 2013). A brief summary of the findings from other pilot case studies that are considered relevant, are mentioned below.

A pilot testing project of EMA on 10 case studies conducted by Jasch and Schnitzer (2002:6) showed that there is clearly lack of communication between the environmental manager and cost accountant in companies.

The environmental manager has limited access to actual cost accounting documents and although the cost controller has most of the information, they lack the ability to separate the environmental part without proper guidance. EMA is a combined approach to bridge this communication gap and provide for the transition of data from cost accounting and financial accounting to reduce the environmental impact by increasing material efficiency. Hence, it was implied that, in order to enable the sharing of environmental information, there was a need to stimulate management accounting practices, formal and informal interactions between different functions. Similar findings were reported by Albelda (2011:76-100) who explored the role of management accounting practices as facilitators of the environmental management.

The results showed that by reinforcing the four significant EMAS elements: commitment to continual improvement of environmental performance; compliance with environmental legislation; communication with stakeholders; and employee involvement, management accounting practices operate as a facilitator mechanism for environmental management.

Poor communication links between the accounting and technical departments result in inaccurate cost allocation, which eventually leads to managers making incorrect operational and investment decisions. This ultimately has inverse impacts on a company's environmental and financial performances. It had been discovered subsequently that many of the businesses' costs are environment-related and that simple actions could be taken to improve environmental and business performances (Jasch and Schnitzer 2002:6). Olson and Jonall (2008:29) mentions in his 
review of corporate results that, when EMA methodology was applied at a Canadian Mackenzie Paper Division paper mill, environmental costs were found to be more than twice as high as those reported in the company's year-end report. This finding concludes that many important environmental costs are hidden in other accounts and supports the view that environmental costs are higher than generally perceived by management.

Porter's hypothesis of the "win-win" scenario states that if environmental regulation was properly designed, it can inspire innovation that will allow companies to use their inputs more productively to offset the costs of improving the environmental impact. Porter suggested that a strategy aimed at enhanced resource productivity will make companies more competitive (Bras et al. 2004).

The two impediments that were identified to using environmental issues to gain competitive advantage were: ignorance about direct and indirect environmental impact; and limitations of conventional accounting systems for tracking environmental costs (Bras et al. 2004). Schaltegger et al. (2010:262) are in agreement with Porter's hypothesis of a winwin situation and stated that EMA can improve efficiency, reduce costs, improve decision making, and competitive advantage. There is however, substantial evidence that indicates that customers prefer companies that adopt measures to innovate to improve their environmental performance, and innovation also improved the image of the business enterprise giving them a competitive edge.

Khalid and Dixon (2012) found that companies with which they do business as well as pressures from customers for environmentally sensitive workplaces play an important role in how a company reacts to environmental issues.

Khalid and Dixon (2012:3) claim that, by using EMA, companies could implement proactive techniques that could prevent or reduce the environmental impact of their operational activities. AbdelKader (2011:67) also discovered contradictory arguments that have also been reported claiming that EMA involves complex analysis such as material balances to track and gather information on environmental costs which are expensive and may not always be cost effective.
It is evident from various case studies that many organisations are not fully aware and knowledgeable on how to actually implement EMA and, therefore, are unable to experience the benefits of EMA implementation. Since this concept is new to many industries, there is clearly a need for more structured guidelines on how to adapt current management accounting practices to include environment-related information. Governments, environmental support groups and other regulatory organizations need to promote and encourage EMA adoption in various industries. EMA implementation remains a "niche" in South Africa as organisations are reluctant to adopt new systems unless they are compelled to do so as a regulatory or legislative requirement.

\section{Conclusion}

There is a lack of awareness among South African companies of the role and importance of EMA in improving environmental and economic performance and achieving sustainable development targets. Therefore, many companies are still using conventional costing systems and are unable to make informed strategic decisions of investing in $\mathrm{CP}$. However, changes in legislation will greatly impact on management's current view on CP and EMA.

This paper has presented an analysis of keys issues on EMA that have been investigated by other researchers. Empirical evidence to support these findings was also discussed. A critical analysis was presented of the different views on the reasons for the challenges that organisations face in adopting an EMA system. Gaps in the studies were also realised during the literature review which allows for further research into tools of EMA.

\section{$4 \quad$ References}

[1] Abdel-Kader G.M. (2011) - Review of Management Accounting Research. United Kingdom. Palgrave Macmillan (63-65).

[2] Ahmad S., Saha P.K., Abbasi A., Khan M. 2009 - Environmental Management Systems and Sustainability: Integrating Sustainability in Environmental Management Systems. Master thesis, 
School of Engineering, Blekinge. Institute of Technology: Karlskrona, Sweden.

[3] Albelda E. (2011) - The role of management accounting practices as facilitators of the environmental management: Evidence from EMAS organisations. Sustainability Accounting, Management and Policy Journal (online), 2(1):76100, http://www.emeraldinsight.com/journal.htm (accessed 9 June 2014).

[4] Ambe M.C. (2007) - Environmental Management Accounting in South Africa. Status, challenges and implementation framework. D. Tech. Tshwane University of Technology.

[5] Bennett M. Schaltegger S., Zvezdov D. (2013) Exploring Corporate Practices in Management Accounting for Sustainability (online), 1-56, http://www.icaew.com/academic (accessed 15 March 2014).

[6] Bennett M., Rikhardsson P., Schaltegger S. (2003) - Adopting environmental management accounting: EMA as a value-adding activity [in] Environmental Management AccountingPurpose and Progress. Springer, 1-14.

[7] Bennett M., Schaltegger S., Zvezdov D. (2011) Environmental management accounting. Review of Management Accounting Research, S: 53-84.

[8] Bras B., Realff M., Carmichael C. (2004) Integrated Environment and Economic Performance Assessment for Strategic Planning and Policy Analysis in Paper Manufacturing. CPBIS project - B-4: 5-7, final project report to CPBIS.

[9] Brent A.C., Premraj S. (2007) - Environmental management systems in the automotive supply chain in South Africa: A pilot study. South African Journal of Industrial Engineering, 18(2):2134.

[10] Burritt R.L., Hahn T., Schaltegger S. (2002) Towards a comprehensive framework for environmental management accounting - Links between business actors and environmental management accounting tools. Australian Accounting Review, 12 (27): 39-50.

[11] Christmann P. (2000) - Effects of "best practices" of environmental management on cost advantage: The role of complementary assets.
Academy of Management journal, 43 (4): 663680.

[12] Darnall N., Henriques I., Sadorsky P. (2008) Do environmental management systems improve business performance in an international setting? Journal of International Management 14:364-376. http://www.sciencedirect.com (accessed 13 February 2014).

[13] De Beer P., Friend F. (2006) - Environmental accounting: a management tool for enhancing corporate environmental and economic performance. Ecological Economics, 58 (3): 548-560.

[14] Environmental Strategies (online), 2013. http://www.unido.org/en/what-we-do/environm ent (accessed 18 March 2014).

[15] Ferenhof H.A., Vignochi L., Selig P.M., Lezana, A.G.R., Campos L.M.S. (2014) - Environmental management systems in small and medium-sized enterprises: an analysis and systematic review. Journal of Cleaner Production (online), 74:4453. (accessed 10 May 2014) http://www.elsevier.com/locate/jclepro.

[16] Ferenhof H.A., Vignochi L., Selig P.M., Lezana A.G.R., Campos L.M.S. (2014) - Environmental management systems in small and medium-sized enterprises: an analysis and systematic review. Journal of Cleaner Production (online), 74:44-53 (accessed 10 May 2014).

http://www.elsevier.com/locate/jclepro

[17] Fore S., Mbohwa G.T. (2010) - Cleaner production for environmental conscious manufacturing in the foundry industry. Journal of Engineering Design Technology (online), 8(3):314-333. (Accessed 21 June 2013). http://dutlib.dut.ac.za:2057/docview/1012253156

[18] Godschalk S. (2008) - Does Corporate Environmental Accounting Make Business Sense. Eco-efficiency in Industry and Science. 24: 249265.

[19] Henriques I., Sadorsky P. (2007) - Environmental Technical and Administrative Innovations in the Canadian Manufacturing Industry. Business strategy and the environment (online), 16:119132. (accessed 10 July 2013). http://www.interscience.wiley.com 
[20] Holt A. (2009) - Environmental management accounting (EMA): empirical evidence from the UK manufacturing sector [in] Management Accounting Research Group (MARG) Conference: Innovation and Sustainability in Management Accounting (online) (accessed 13 March 2014). http://www2.lse.ac.uk/accounting/news

[21] Hyrslova' J., Vagner M., Palasek J. (2011) Material Flow Cost Accounting (MFCA) - Tool For The Optimization of Corporate Production Processes. Business, Management and Education 9(1): 5-18.

[22] Introducing Environmental Management Accounting at Enterprise level (2001) - Methodology and case studies from Central and Eastern Europe. United Nations Industrial Development Organisation.

[23] Jalaludin D., Sulaiman M., Ahmad N.N.N. (2011) - Understanding environmental management accounting (EMA) adoption: a new institutional sociology perspective (online), 7(4):540557. http://www.emeraldinsight.com (accessed 13 March 2014).

[24] Jasch C. (2003) - The use of Environmental Management Accounting (EMA) for identifying environmental costs. Journal of Cleaner Production, 11 (6): 667-676.

[25] Jasch C., Schnitzer H. (2002) - Environmental Management Accounting. How to profit from environmental protection. EMA- environmental management accounting pilot testing.

[26] Khalid F.M., Lord B., Dixon R. (2012) - Environmental management accounting implementation in environmentally sensitive industries in Malaysia. $6^{\text {th }}$ NZ Management Accounting Conference. University of Canterbury, New Zealand.

[27] Lakhani M. (2007) - The need for Clean Production and Product Re-design. Journal of Cleaner Production, 15 (13): 1391-1394.

[28] Lambert S.C., Carter A.J., Burritt R.L. (2012) Recognising commitment to sustainability through the Business Model. Centre for Accounting, Governance and Sustainability. University of South Australia.
[29] Li X. (2004) - Theory and practice of environmental management accounting: experience of implementation in China. International Journal of Technology Management and Sustainable Development, 3(1):47-57.

[30] Mohr-Swart M. (2008) - An Environmental Management Accounting Model for the South African Mining Industry. Doctor of Technology in the Department of Environmental, Water and Earth Sciences, Tshwane University of Technology.

[31] Olson O., Jonall P. (2008) - Environmental Management Accounting (EMA), Management Accounting including Environmental Management - a literature review.

[32] Orsato R.J. (2006) - Competitive Environmental Strategies: When Does It Pay To Be Green? California Management Review (online), 48(2):127133. http://dutsummon.com (accessed 12 May 2014).

[33] Qian W., Burritt R. (2008) - The Development of Environmental Management Accounting: An Institutional View [in] Schaltegger S., Bennett M., Burritt R., Jasch C. eds. Environmental Management Accounting for Cleaner Production. Springer Netherlands, 233-248. Available: http://dx.doi.org/10.1007/978-1-4020-8913-8_12 (Accessed 19 October 2013).

[34] Qian W., Burritt R., Monroe G. (2011) - Environmental management accounting in local government: A case of waste management. Accounting, Auditing \& Accountability Journal, 24 (1): 93-128.

[35] Radonjič G., Tominc P. (2007) - The role of environmental management system on introduction of new technologies in the metal and chemical/paper/plastics industries. Journal of Cleaner Production, 15 (15): 1482-1493.

[36] Resource Efficient and Cleaner Production (2013). (online) http://www.unido.org/en/whatwe-do/environmental/resource-efficient (accessed 18 March 2014).

[37] Scavone G.M. (2006) - Challenges in internal environmental management reporting in Argentina. Journal of Cleaner Production (online), 14:1276-1285. (accessed 23 October 2013) http://www.sciencedirect.com. 
[38] Schaltegger S., Bennett M., Burritt R.L., Jasch C. (2010) - Eco-efficiency in industry and science. Environmental Management Accounting for Cleaner Production. $5^{\text {th }}$ edition. Springer Science and Business Media. UK.

[39] Schaltegger S., Gibassier D., Zvezdov D. (2011) - Environmental Management Accounting. A Bibliometric Literature Review. Centre for Sustainability Management.

[40] Sinclair-Desgagne B. (2004) - Corporate Strategies for Managing Environmental Risk. The International Library of Environmental Economics and Policy xx:1-7. Scientific Series 2004, s-43, Montreal.
[41] South Africa (2004) - National Cleaner Production Strategy. Draft 2. Pretoria: Government printer (online). http://unep.or.jp/ietc/knowledge (accessed 31 July 2013).

[42] Stringer L. (2010) - The Green Workplace- Sustainable strategies that benefit employees, the environment, and the bottom line. Paperback edition. New York: Palgrave Macmillan. 